\title{
CORRELATION OF LEPTIN LEVEL WITH OBESITY.
}

\footnotetext{
1. MBBS, M.Phil

Assistant Professor Physiology

$\mathrm{CMH}$ Institute of Medical Sciences

Bahawalpur.

2. MBBS, M.Phil

Assistant Professor Physiology

Sharif Medical and Dental College

Lahore.

3. M.Sc. (IT), M.Phil. (Computer Sciences)

Assistant Professor Computer Science

Sharif College of Nursing Lahore.
}

Correspondence Address:

Dr. Jazib Andleeb

Assistant Professor Physiology

$\mathrm{CMH}$ Institute of Medical Sciences

Bahawalpur.

jazibsaqlain@gmail.com

Article received on:

13/05/2019

Accepted for publication:

14/12/2019

\section{INTRODUCTION}

Leptin is a hormone protein that plays an important role in regulation of body weight and metabolism. ${ }^{1}$ Leptin was discovered in 1994 and give too much attention in the field of metabolic research and Obesity. Obesity is an excessive amount of body fat which produces adverse health consequences worldwide. ${ }^{2}$ The traumatic increase in frequency of obesity has been observed; about 60 to $65 \%$ are overweight or obese now. Main cause of the obesity is energy homeostasis that means a balance between energy intake, energy expenditure and storage. According to the 2016 World Health Organization (WHO) statistics, $20.8 \%$ of the population is overweight and $4.8 \%$ is obese. ${ }^{3}$

An increase, decrease and maintenance of body weight related to the balance between energy intake and expenditure. ${ }^{4}$ The energy intake means the use of food in 24 hours and energy expenditure is a complex thermo genesis process which is a combination of adoptive thermo genesis, basal metabolism and daily physical activities. ${ }^{5}$
Among these adoptive thermo genesis is an increase production of heat due to metabolic cycles running in human body in response of behavioral and environmental changes which may include consumption of excessive food, composition of diet and number of pathogenic stimuli. ${ }^{6,7}$ Leptin secreted by adipocytes direct into the blood stream and present in serum. Its primary role is to provide signals to the central nervous system about energy store and command the human body to make adjustment about the energy intake and expenditure. ${ }^{8}$

Main role of leptin is to act as a gate keeper to activity which is essential and necessary for the survival and reproduction. ${ }^{9}$ Leptin controls food intake by binding to the receptors in central nervous system and modulator for the activities of neuron to control the appetite and use of food. Sometimes obese develop very high plasma leptin concentrations and fails to reduce appetite or enhance the energy expenditure. ${ }^{10}$ This study was unique analysis at our setup as no local study available before in this region that trends towards research and problem solving step of obesity. 


\section{MATERIAL \& METHODS}

This observational comparative study was conducted at $\mathrm{CMH}$ Institute of Medical Sciences Bahawalpur, Sharif Medical and Dental College and Sharif College of Nursing Lahore from January 2018 to January 2019. The study was conducted on 90 healthy obese and non-obese subjects who were selected by non-probability consecutive sampling technique. Patients with BMl of 23 to $27 \mathrm{~kg} / \mathrm{m} 2$ were labeled as overweight. ${ }^{11}$ 27 to $40 \mathrm{~kg} / \mathrm{m} 2$ were labeled as obese. 18 to $23 \mathrm{~kg} /$ $\mathrm{m} 2$ we're labeled as non-obese. ${ }^{11}$ The study was started after the ethical approval from the ethical board of hospital after detailed information to the participating subjects. Laboratory and clinical data was collected from all subjects to present as outdoor department of hospital. Sample size calculated by using online software openepi.com.

Height of the patients was measured by using stadiometer and weight was calculated by weighing weight balance. BMl was calculated by using formula weight in kgs over height in m2. After an overnight fasting blood samples were obtained in morning time and blood was saved into a plane tube and left for clotting at room temperature. After 20 minutes of sample collecting blood was centrifuged for 10 minutes at the speed of 2000 to $3000 \mathrm{G}$ and serum was collected for leptin analysis. Sandwich enzyme linked immunosorbent assay (Elisa) was used for determination for leptin. Obese patients according to standard definition of obesity were included in the study. Patients with chronic or systemic illness (liver cirrhosis, renal failure, and cardiac diseases), hypertension, diabetes, depression and pregnant women were excluded from the study .

Statistical analysis of data was performed by using SPSS version 23. Mean and standard deviation we're calculated for numbers like age and leptin range level. Frequency and percentage were calculated for data analysis of qualitative variables. T-test and chi square tests were applied to see association among variables. $P$ value less than or equal to 0.05 was considered as significant.

\section{RESULTS}

Ninety patients were included in this study, both gender. The patients were divided into two groups as obese and non-obese. The mean age and BMI of the obese patients was $35.06 \pm 4.11$ years and $31.71 \pm 2.28 \mathrm{~kg} / \mathrm{m}^{2}$, respectively. There were $\mathrm{n}=30$ (66.7\%) males and $n=15$ (33.3\%) females. While, the mean age and BMI of the non-obese patients was $30.11 \pm 3.55$ years and $21.48 \pm 1.71 \mathrm{~kg} / \mathrm{m}^{2}$, respectively. There were $n=34(75.6 \%)$ males and $n=11$ (24.4\%) females. The differences were statistically significant except gender $(p=0.352)$. (Table-I).

The mean leptin level in obese and non-obese was $53.75 \pm 7.54$ and $50.62 \pm 7.18$, respectively. There difference was statistically significant among the groups, $(p=0.000)$. (Table-II).

\begin{tabular}{|c|c|c|c|}
\hline Variable & $\begin{array}{c}\text { Obese } \\
n=45\end{array}$ & $\begin{array}{c}\text { Non-obese } \\
n=45\end{array}$ & P-Value \\
\hline Age (years) & $35.06 \pm 4.11$ & $30.11 \pm 3.55$ & 0.001 \\
\hline BMI $\left(\mathrm{kg} / \mathrm{m}^{2}\right)$ & $31.71 \pm 2.28$ & $21.48 \pm 1.71$ & 0.001 \\
\hline \multicolumn{4}{|c|}{ Gender } \\
\hline Male & $\mathrm{n}=30(66.7 \%)$ & $n=34(75.6 \%)$ & \multirow{2}{*}{0.352} \\
\hline Female & $n=15(33.3 \%)$ & $n=11(24.4 \%)$ & \\
\hline \multicolumn{4}{|c|}{ Table-I. Demographic characteristics of both groups. } \\
\hline Variable & $\begin{array}{l}\text { Obese } \\
n=45\end{array}$ & $\begin{array}{c}\text { Non-obese } \\
n=45\end{array}$ & P-Value \\
\hline Leptin level & $53.75 \pm 7.54$ & $48.21 \pm 7.18$ & 0.001 \\
\hline \multicolumn{4}{|c|}{$\begin{array}{c}\text { Table-II. Leptin level in obese and non-obese } \\
\text { patients. }\end{array}$} \\
\hline
\end{tabular}

\section{DISCUSSION}

In our study we found raised leptin level in obese patients as compare to non-obese which means that leptin resistance is the prominent cause of obesity in humans. In a previous study conducted by Lönnqvist $\mathrm{F}$ et $\mathrm{al}^{12}$ also reported similar effect, he conducted a study on patients of cardiovascular patients and concluded that leptin level was found elevated in obese presented with cardiovascular events. In his study this level was not found increased in non-obese cardiac patients.

In another study conducted by Smith JD et $\mathrm{al}^{13}$ found that leptin level was not found in obese 
patients who were aged over 65 years. Results of this study shows that leptin level highly bounded to age of patients, increase in age reduce that patient's leptin. A study was conducted by Ostlund et $\mathrm{al}^{14}$ and concluded that patients with age limit above 65 years have negative correlations between leptin and body weight. Below 65 years patients have raised level of leptin as compare to above 65 years. A decrease in leptin levels originates by adipose tissue may be responsible for this difference.

In contrast to two studies given above many studies prove positive correlation between age and leptin level. As a study was conducted by Shamsuzzaman AS et $\mathrm{al}^{15}$ on Independent association between plasma leptin and C-reactive protein in healthy humans and found positive correlations among two variables.

Stagier $\mathrm{H}$ et $\mathrm{al}{ }^{16}$ conducted a study and reported positive correlation between leptin resistance and hip waist ratio (HWR), body mass index as our study also found positive correlation with body mass index (BMI). On other hand Liuzzi $A$ et al ${ }^{17}$ reported negative correlation with leptin resistance and HWR. In his study positive correlation was found in male subjects and negative correlation was observed in female.

Another similar study was conducted by Lyoussi $\mathrm{B}$ et $\mathrm{al}^{18}$ and observed that positive correlation was present in male sunjects and negative correlation was found in female subjects. This study also favors the study of Liuzzi $A$ et al $^{19}$, gender-related difference may be due to visceral fat tissue in males and greater abundance of subcutaneous fat tissue in females subjects.

Scarpace $\mathrm{PJ}$ et al ${ }^{19}$ conducted a study on relation of obesity and leptin elevation and observed strong correlation between both. He reported that once leptin resistance takes control of body mechanism every high density food will results extensive weight gain. As related to its prevention treatment of leptin resistance in childhood will confers exposure protection from obesogenic food and environment. ${ }^{20,21}$

\section{CONCLUSION}

Leptin level is a related factor in the pathogenesis of obesity, further more among different diseases increased leptin level is responsible significantly. Copyright $@ 14$ Dec, 2019.

\section{REFERENCES}

1. Crujeiras $A B$, Carreira MC, Cabia B, Andrade $S$, Amil M, Casanueva FF. Leptin resistance in obesity: An epigenetic landscape. Life Sci. 2015; 140:57-63.

2. Mazor R, Friedmann-Morvinski D, Alsaigh $\mathrm{T}$, Kleifeld $\mathrm{O}$, Kistler EB, Rousso-Noori $\mathrm{L}$ et al. Cleavage of the leptin receptor by matrix metalloproteinase-2 promotes leptin resistance and obesity in mice. Sci Transl Med. 2018; 10(455):00-00.

3. World Health Organization 2016. [online] [Cited 2016 Dec 22]. Available from: URL: http://www.who.int/ diabetes/country-profiles/pak_en.pdf?ua $=1$.

4. Ottaway N. et al. Diet-induced obese mice retain endogenous leptin action. Cell Metab. 2015; 21:877882.

5. De Git KC, Adan RA. Leptin resistance in diet-induced obesity: the role of hypothalamic inflammation. Obesity reviews. 2015 Mar;16(3):207-24.

6. Dodd GT et al. Leptin and insulin act on POMC neurons to promote the browning of white fat. Cell 2015; 160:88-104.

7. Lanaspa MA, Kuwabara M, Andres-Hernando A. High salt intake causes leptin resistance and obesity in mice by stimulating endogenous fructose production and metabolism. Proc Natl Acad Sci U S A. 2018; 115(12):3138-43.

8. de Git KC, Adan RA. Leptin resistance in diet-induced obesity: The role of hypothalamic inflammation. Obes Rev. 2015; 16(3):207-24.

9. Platt TL, Beckett TL, Kohler K, Niedowicz DM, Murphy MP. Obesity, diabetes, and leptin resistance promote tau pathology in a mouse model of disease. Neuroscience. 2015; 315:162-74.

10. Altirriba J, Poher AL, Rohner-Jeanrenaud F. Chronic oxytocin administration as a treatment against impaired leptin signaling or leptin resistance in obesity. Front Endocrinol (Lausanne). 2015; 6:119.

11. Najjar MF, Rowland M1987 Anthropometric reference data and prevalence of overweight, United States, 1976-80. Vital Health Stat 11:1-73. 
12. Lönnqvist F, Wennlund A, Arner P. Relationship between circulating leptin and peripheral fat distribution in obese subjects. Int J Obes Relat Metab Disord. 1997; 21:255-60.

13. Smith JD, Al-Amri M, Sniderman AD, Cianflone K. Leptin and adiponectin in relation to body fat percentage, waist to hip ratio and the apoB/apoAl ratio in Asian Indian and Caucasian men and women. Nutr Metab. 2006; 3:18-26.

14. Ostlund RE, Yang JW, Klein S, Gingericj R. Relation between plasma leptin concentration and body fat, gender, diet, age and metabolic covariates. J Clin Endocrinol Metab. 1996; 81:3909-13.

15. Shamsuzzaman AS, Winnicki M, Wolk R. Independent association between plasma leptin and C-reactive protein in healthy humans. Circulation. 2004; 109:2181-85.

16. Staiger $H$, Tschritter $O$, Machann J. Relationship of serum adiponectin and leptin concentrations with body fat distribution in humans. Obes Res. 2003; 11:368-72.
17. Liuzzi A, Savia G, Tagliaferri M. Serum leptin concentration in moderate and severe obesity: Relationship with clinical, anthropometric, and metabolic factors. Int J Obes Relat Metab Disord. 1999; 23:1066-73.

18. Lyoussi B, Ragala MA, Mguil M, Chraibi A, Israili ZH. Gender-specific leptinemia and its relationship with some components of the metabolic syndrome in Moroccans. Clin Exp Hypertens.2005; 4:377-94.

19. Scarpace PJ, Zhang Y. Elevated leptin: Consequence or cause of obesity? Front Biosci. 2007; 12:3531-44.

20. Sánchez-Hernández D, Cho CE, Kubant R, Reza-López $\mathrm{SA}$, Poon AN, Wang $\mathrm{J}$ et al. Increasing vitamin $\mathbf{A}$ in post-weaning diets reduces food intake and body weight and modifies gene expression in brains of male rats born to dams fed a high multivitamin diet. J Nutr Biochem. 2014; 25(10):991-6.

21. Palou M, Picó C, McKay JA, Sánchez J, Priego T, Mathers JC et al. Protective effects of leptin during the suckling period against later obesity may be associated with changes in promoter methylation of the hypothalamic pro-opiomelanocortin gene. $\mathrm{Br} \mathrm{J}$ Nutr. 2011; 106(5):769-78.

\begin{tabular}{|c|c|c|c|}
\hline \multicolumn{4}{|c|}{ AUTHORSHIP AND CONTRIBUTION DECLARATION } \\
\hline Sr. \# & Author(s) Full Name & Contribution to the paper & Author(s) Signature \\
\hline 1 & Jazib Andleeb & Conceive idea, Design study. & (splet) \\
\hline 3 & Rukhsana Abdul Karim & Data Collection, Data Analysis. & Q \\
\hline
\end{tabular}

